\title{
Effect of Dietary Inclusion of Alpha-Monolaurin on the Growth Performance, Lipid Peroxidation, and Immunity Response in Broilers
}

\author{
Ahmed Ali Saleh ${ }^{1, *(\mathbb{D}}$, Bahaa El-Gharabawy ${ }^{1}$, Aziza Hassan ${ }^{2} \mathbb{D}$, Nemat Badawi ${ }^{1}$, Yahya Eid ${ }^{1} \mathbb{D}$, Shaimaa Selim $^{3}$ \\ Mustafa Shukry ${ }^{4}$ and Mahmoud Dawood ${ }^{5}$ (D)
}

1 Department of Poultry Production, Faculty of Agriculture, Kafrelsheikh University, Kafr El-Sheikh 33516, Egypt; Feedmillspecialist@gmail.com (B.E.-G.); ahmedsaleh200@gmail.com (N.B.); yahyaze@gmail.com (Y.E.)

2 Department of Biotechnology, College of Science, Taif University, P.O. Box 11099, Taif 21944, Saudi Arabia; a.hasn@tu.edu.sa

3 Department of Nutrition and Clinical Nutrition, Faculty of Veterinary Medicine, Menoufia University, Shibin El-Kom 32514, Egypt; shimaaselim@vet.menofia.edu.eg

4 Department of Physiology, Faculty of Veterinary Medicine, Kafrelsheikh University, Kafr El-Sheikh 33516, Egypt; mostafa.ataa@vet.kfs.edu.eg

5 Department of Animal Production, Faculty of Agriculture, Kafrelsheikh University, Kafr El-Sheikh 33516, Egypt; mahmouddawood55@gmail.com

* Correspondence: ahmed.saleh1@agr.kfs.edu.eg

check for updates

Citation: Saleh, A.A.; El-Gharabawy, B.; Hassan, A.; Badawi, N.; Eid, Y.; Selim, S.; Shukry, M.; Dawood, M. Effect of Dietary Inclusion of Alpha-Monolaurin on the Growth Performance, Lipid Peroxidation, and Immunity Response in Broilers. Sustainability 2021, 13, 5231. https:// doi.org/10.3390/su13095231

Academic Editors: George Symeon and Lars Olav Eik

Received: 27 March 2021

Accepted: 26 April 2021

Published: 7 May 2021

Publisher's Note: MDPI stays neutral with regard to jurisdictional claims in published maps and institutional affiliations.

Copyright: (c) 2021 by the authors. Licensee MDPI, Basel, Switzerland. This article is an open access article distributed under the terms and conditions of the Creative Commons Attribution (CC BY) license (https:/ / creativecommons.org/licenses/by/ $4.0 /)$.
Abstract: As the world population increases, there will be an increase in demand for poultry meat. To satisfy this requirement, sustainably will be a significant challenge as different countries in the world face different health problems. Additionally, for decades, poultry nutritionists have worked on sustainability in broiler manufacturing plants. The usage of short- and medium-chain fatty acids (MCFAs), which have positive effects as growth promoters and immunostimulants, is a pioneering way to decrease the cost of diets and improve environmentally friendly and sustainable production in this critical era. This study aimed at evaluating the influences of alpha-monoglyceride (alphamonolaurin) on the growth performance, biochemical parameters, lipid profiles, liver oxidative stress, and immune response in broilers. Alpha-monolaurin was included at the levels of 0 (control), 0.25 , 0.5 , and $1 \mathrm{~g} / \mathrm{kg}$ in broiler diets. After 33 days, dietary supplementation of alpha-monolaurin showed no impact on the feed intake; however, broilers fed $0.5 \mathrm{~g} / \mathrm{kg}$ feed displayed a significantly reduced food conversion ratio, as compared to the control ( $p \leq 0.05$ ). However, body weight and body weight gain tended to increase after $0.25 \mathrm{~g} / \mathrm{kg}$ alpha-monolaurin supplementation, as compared to other groups. The highest European production efficiency factor (EPEF) was obtained with $0.25 \mathrm{~g} / \mathrm{kg}$ alpha-monolaurin supplementation. The ether extract utilization and spleen weight were improved substantially ( $p \leq 0.05$ ) by alpha-monolaurin supplementation, but muscle and other organ weights were not affected. Plasma alanine transaminase (ALT) was decreased significantly by alpha-monolaurin supplementation, while plasma total protein and albumin were enhanced $(p \leq 0.05)$. Interestingly, broilers fed alpha-monolaurin displayed an increased antibody titer of the Newcastle disease (ND) virus and muscle unsaturated fatty acid content, and a decreased liver content of malondialdehyde (MDA). It could be assumed that dietary supplementation of alphamonolaurin positively impacts birds' feed efficiency and immune response and can be applied as a natural immune enhancer in the broiler industry.

Keywords: alpha-monolaurin; broilers; lipid peroxidation; fatty acids; immunity

\section{Introduction}

Poultry production is required to provide consumers with a safe and healthy animal protein source [1]. The wellbeing of broiler producers is of increasing concern due to 
conditions such as colibacillosis, necrotic enteritis, Newcastle disease, and gangrenous dermatitis, which lead to the loss of billions of dollars through reduced performance and mortality [2]. Furthermore, birds suffer from a wide range of stressors in farms, including high-density stocking and a lack of farm environmental control, which deteriorate the biosecurity and affect bird health [3]. The broiler industry's profitability may decrease due to different factors, such as improper nutrition and management and a high level of mortality due to viral and bacterial disease infections. The application of immunostimulants is the most effective strategy to cope with bacterial and virus infections in broilers [4] However, the continuous usage of antibiotics as growth promoters and antibacterial agents threatens the natural immunity of birds and causes environmental hazards [5]. Another defect is the inaccuracy of controlling all pathogenic microorganisms, due to antibiotics' species-specific function. Therefore, a plethora of studies investigated the potential role of natural alternatives to antibiotics for healthy broilers [6-8].

Short- and medium-chain fatty acids (MCFAs) are used as alternatives to broiler antibiotics with positive effects such as acting as growth promoters and immunostimulants $[9,10]$. Alpha-monolaurin is one of the alpha-monoglycerides that belong to the MCFAs and can increase bird resistance to bacterial and viral infections [11,12]. In this sense, alphamonolaurin is well known for its inhibitory effects against pathogenic microorganisms in the gut and its antibacterial and antiviral properties [13]. Monolaurin is characterized by its stability in high-heat and acidic conditions with non-corrosive and volatile properties in the bird's gut. It also increases feed intake and digestibility because of its suitable taste and flavor [14]. MCFAs play a decisive role in absorption through the intestinal villi, by facilitating the fluidity of nutrients to the bloodstream [15].

The medium-chain fatty acid lauric acid (C12) is commonly found in natural products such as coconut oil. Alpha-monolaurin can be formed by esterification of lauric acid to the sn-1 position of the glycerol molecule and has antipathogenic properties that are likely to result in destabilization and disintegration of the pathogen through solubilization of lipids and phospholipids in the bacterial cell membrane [16]. Additionally, alpha-monolaurin is biologically more active than non-esterified lauric acid in neutralizing viruses and bacteria [17]. Alpha-monolaurin is thus commercially available as a beneficial feed additive that improves health and the efficiency of poultry production [18]. Witcher et al. reported that monolaurin boosts the immune system by increasing $T$ cell lymphocyte growth [19]. Monolaurin also improves the immune system through the stimulation of splenocyte and $\mathrm{T}$ cell proliferation. This shows that monolaurin affects the $\mathrm{T}$ cell populations in particular. Monolaurin can lead to $\mathrm{T}$ cell proliferation in the transduction pathway of the phospholipid inositol signal. The presence of calcium, which affects human signaling and the function of $\mathrm{T}$ cells, supports this mechanism, consequently decreasing the cytokine creation [20].

Newcastle disease is a virulent infection of domestic poultry and other bird species via the virulent Newcastle disease virus (NDV). It is a worldwide issue presented predominantly as an acute respiratory disorder, although the prevalent clinical type can be depression, nervous manifestations, or diarrhea. Severity depends upon virulence and host susceptibility. Poultry scientists found that alpha-monolaurin dietary supplements possess more robust antiviral properties against NDV. The antiviral properties of lauric acid are more potent than other fatty acids. When maturing the replication cycle, lauric acid inhibits the virus via an inhibitor mechanism [21]. Laurate in the form of alpha-monolaurin is more biologically active in destroying bacteria and viruses than free lauric acid, whereas in the form of diacylglycerols and lauric acid, triacylglycerols are not effective against microorganisms [17]. According to other studies, monolaurin acts as an antiviral agent by interfering with the organism's signal transduction systems, as well as the processes of viral RNA assembly and virus maturation and dissemination [22]. Monolaurin has been reported to have the ability to combat different forms of viruses (e.g., Newcastle disease (ND)). Hilmarsson et al. indicated that monoacylglycerols with medium-chain fatty acids such as monocaprylin, monocaprin, and monolaurin have strong virucidal effects on influenza viruses such as HPIV2 and RSV [23]. Recently, Mustafa [24] reported that chicks fed diets 
with monolaurin displayed enhanced growth and immunological performances. However, no studies were performed to reveal dietary monolaurin's influence against Newcastle disease (ND) and the hepatic malonaldehyde concentration in broilers. The current study uniquely evaluated the effects of alpha-monolaurin on the growth rate, nutrient utilization, biochemical blood indices, lipid peroxidation, and resistance to ND in broilers.

\section{Material and Methods}

\subsection{Experimental Design}

A total of 480 mixed-sex one-day-old broilers (Ross 308) were housed in pens with a stocking density of 10 birds $/ \mathrm{m}^{2}$ and separated into four experimental groups with 6 replicates each (20 birds). The control group was fed commercial feed formulated following the strain requirements as basal diets. Three experimental groups were supplemented with the basal diet with $0.25,0.5$, and $1 \mathrm{~g} / \mathrm{kg}$ feed of alpha-monolaurin. The formulation of diets is presented in Table 1. The feed was supplied to the birds ad libitum. Starter diets were in crumble form; the grower and finisher diets were in pellet form. The alpha-monolaurin used in this study was a commercial product called (Laurix) ${ }^{\circledR}$ and was provided by the Animal Nutrition Development Group, S.L, LTD., Las Rozas, Madrid, Spain.

Table 1. Composition and calculated levels of the basal diets.

\begin{tabular}{|c|c|c|c|}
\hline Ingredient, \% & $\begin{array}{c}\text { Starter } \\
0-14 \text { Days }\end{array}$ & $\begin{array}{c}\text { Grower } \\
\text { 15-24 Days }\end{array}$ & $\begin{array}{c}\text { Finisher } \\
\text { 25-33 Days }\end{array}$ \\
\hline Yellow corn & 55.551 & 59.553 & 62.0 \\
\hline Soybean meal, $46 \%$ & 38.9 & 34.268 & 31.3 \\
\hline Corn gluten meal, $60 \%$ & 0.764 & 0.962 & 0.556 \\
\hline Soya oil & 1.0 & 1.795 & 2.974 \\
\hline Calcium carbonate & 1.465 & 1.325 & 1.231 \\
\hline Mono calcium phosphate & 1.028 & 0.838 & 0.715 \\
\hline Salt & 0.261 & 0.289 & 0.291 \\
\hline Sodium bicarbonate & 0.131 & 0.095 & 0.095 \\
\hline DL methionine, $99 \%$ & 0.299 & 0.262 & 0.237 \\
\hline L-Lysine $\mathrm{HCl}, 98 \%$ & 0.154 & 0.17 & 0.162 \\
\hline L-Threonine & 0.062 & 0.058 & 0.054 \\
\hline Premix * & 0.2 & 0.2 & 0.2 \\
\hline Anticoccidia (dicalzoril) & 0.02 & 0.02 & 0.02 \\
\hline Antimycotoxin & 0.15 & 0.15 & 0.15 \\
\hline Phytase 500 FTU & 0.015 & 0.015 & 0.015 \\
\hline Total & 100 & 100 & 100 \\
\hline \multicolumn{4}{|c|}{ Chemical Analysis on DM basis } \\
\hline AME kcal & 2899.678 & 2999.676 & 3099.678 \\
\hline Crude protein, \%. & 22.868 & 21.109 & 19.646 \\
\hline Fat, \% & 3.883 & 4.761 & 5.95 \\
\hline Digestible LYS, \% & 1.4 & 1.29 & 1.2 \\
\hline $\begin{array}{l}\text { Digestible methionine and } \\
\text { cysteine, } \%\end{array}$ & 1.008 & 929 & 0.864 \\
\hline Digestible THR, \% & 0.952 & 0.929 & 0.864 \\
\hline Digestible ARG, \% & 1.486 & 1.354 & 1.26 \\
\hline
\end{tabular}


Table 1. Cont.

\begin{tabular}{cccc}
\hline Ingredient, \% & $\begin{array}{c}\text { Starter } \\
\text { 0-14 Days }\end{array}$ & $\begin{array}{c}\text { Grower } \\
\text { 15-24 Days }\end{array}$ & $\begin{array}{c}\text { Finisher } \\
\text { 25-33 Days }\end{array}$ \\
\hline Digestible ILE, \% & 0.997 & 0.91 & 0.842 \\
\hline Digestible LEU, \% & 1.849 & 1.734 & 1.607 \\
\hline Digestible VAL, \% & 1.106 & 1.019 & 0.948 \\
\hline Calcium, \% & 0.96 & 870 & 0.81 \\
\hline Available P, \% & 0.48 & 0.435 & 0.405 \\
\hline Sodium, \% & 0.16 & 0.16 & 0.16 \\
\hline Chloride, \% & 0.25 & 0.25 & 0.23 \\
\hline
\end{tabular}

${ }^{*}$ Multiveta ${ }^{\circledR}$ (Multiveta, Cairo, Egypt). Composition (per 2 kg): vitamin A 12,000,000 IU, vitamin D3 2,500,000 IU, vitamin E 10,000 mg, vitamin K3 2000 mg, vitamin B1 1000 mg, vitamin B2 5000 mg, vitamin B6 1500 mg, vitamin B12 $10 \mathrm{mg}$, niacin 30,000 mg, biotin $50 \mathrm{mg}$, folic acid $1000 \mathrm{mg}$, pantothenic acid 10,000 mg, manganese $60,000 \mathrm{mg}$, zinc 50,000 mg, iron 30,000 mg, copper $4000 \mathrm{mg}$, iodine $300 \mathrm{mg}$, selenium $100 \mathrm{mg}$, and cobalt $100 \mathrm{mg}$.

The Bursaplex ${ }^{\circledR}$ (Zoetis; Taguig City, Philippines) and ND + H9 Merial hatchery vaccination programs were used, followed by NOBILIS ${ }^{\circledR}$ IB 4-91 and MA5 + CLONE 30 MSD at one day of age, cloned live ND LaSota (strain Clone 30) at 10 days, and, finally, Bursine Plus ${ }^{\circledR}$ (Zoetis Inc., Kalamazoo, MI, USA) at 14 days. The trial conditions were a $23 \mathrm{~h}$ light-1 h dark cycle in an open-door building. Daily temperature and humidity inside the house were monitored at $24-26{ }^{\circ} \mathrm{C}$ and $60-70 \%$, respectively.

\subsection{Growth Performance and Digestibility}

Body weight and feed intake were assessed individually every week (on a group basis per pen) for the entire experimental period (33 days). Mortality was recorded daily throughout the experimental period. At 30 days, all birds were weighed individually. Then, 12 birds/treatment ( 6 male +6 female) with a consistent average weight were transferred to special batteries containing individual cages for the digestibility experiment. The birds were then slaughtered and dissected to measure the muscle, thigh muscle, liver, heart, spleen, gizzard, and abdominal fat. Every organ was weighed and defined as a living body weight ratio.

During the last three days of the experiment, excreta was collected and weighed from 12 males/group. Broilers were individually stored in special metabolic cages for digestibility tests $(40 \times 40 \times 50 \mathrm{~cm})$. During these three days, the birds and their feed intake were weighted regularly, and the extracted feces was collected, weighed, and frozen. All samples were dried in a drying oven at $60{ }^{\circ} \mathrm{C}$ for one day. Then, the whole dried samples were homogenized. Samples were taken and finely ground for laboratory analysis following the Association of Official Analytical Chemists guidelines [25].

\subsection{Biochemical Analysis}

Before slaughtering, blood samples were extracted and then collected in heparinized test tubes and rapidly centrifuged to isolate the plasma (3000 rpm for $20 \mathrm{~min}$ at $5{ }^{\circ} \mathrm{C}$ ). Plasma was stored at $-20^{\circ} \mathrm{C}$ until analysis. Plasma triglycerides (TGs), total cholesterol, high-density lipoprotein (HDL) cholesterol, low-density lipoprotein (LDL) cholesterol, alanine transaminase (ALT), aspartate aminotransferase (AST), glucose, creatinine, total protein, albumin, and globulin were tested colorimetrically using commercial kits (Diamond Diagnostics, Cairo, Egypt).

\subsection{Fatty Acid Profile and Malondialdehyde}

Muscle total lipid and fatty acid profiles were assessed using gas-liquid chromatography (GLC) (IET, International Equipment Trading Ltd., Mundelein, IL, USA) following Saleh [26]. Lipid peroxidation was evaluated by assaying the malondialdehyde (MDA) levels in the liver using kits from Cell Biolabs Inc. (San Diego, CA, USA). 


\subsection{Infection Trial}

At 24 days, five birds/replicate were taken to a particular room for ND infection $(2 \mathrm{~mL}$ eye and nasal drops ND genotype 7, NCBI reference: M445410.avian orthoavulavirus 1), and $\mathrm{HI}$ titers were measured for ND at 7, 14, and 21 days post-ND infection. Serum antibody titers against Newcastle disease (ND) were analyzed using the hemagglutination inhibition test utilizing standard methods qualified by OIE [27].

\subsection{Statistical Analysis}

A general linear model was utilized to evaluate differences between the groups, applying SPSS Statistics (version 17.0, SPSS Inc., Chicago, IL, USA). Tukey's multiple comparison test was used to detect which treatment conditions were significantly different from each other.

\section{Results}

\subsection{Growth Efficiency, Digestibility, and Organ Weight}

Results concerning the effect of dietary alpha-monolaurin supplementation on growth performance and nutrient utilization are illustrated in Table 2. Growth performance (body weight, feed intake, and feed conversion) was not affected in experimental groups during the first three weeks of age compared to the control group, except the feed conversion ratio at 14 and 21 days by 0.25 and $0.5 \mathrm{~g} / \mathrm{kg}$ alpha-monolaurin supplementation, but at 28 days, body weight and the feed conversion ratio were improved by 0.25 and $0.5 \mathrm{~g} / \mathrm{kg}$ with alpha-monolaurin supplementation compared to other groups. Dietary $0.5 \mathrm{~g} / \mathrm{kg}$ alphamonolaurin had a significantly positive impact on the feed conversion ratio concerning the control $(p \leq 0.05)$. The European production efficiency factor and ether extract utilization were improved by alpha-monolaurin supplementation with $0.25 \mathrm{~g} / \mathrm{kg}$ alpha-monolaurin $(p \leq 0.05)$. Body weight gain was statistically increased with $0.25 \mathrm{~g} / \mathrm{kg}$ alpha-monolaurin compared to other groups but was not significant. However, feed intake, crude protein, and crude fiber utilization were not affected by alpha-monolaurin supplementation. Experimental groups did not influence the mortality rate.

Data in Table 3 show the effect of dietary alpha-monolaurin supplementation on organ weights. Carcass, muscle, liver, gizzard, heart, and abdominal fat weights were not significantly influenced by alpha-monolaurin supplementation; however, a significant increase in the spleen weight was detected in 0.25 and $0.5 \mathrm{~g} / \mathrm{kg}$ alpha-monolaurin $(p \leq 0.05)$.

Table 2. Impact of dietary alpha-monolaurin supplementation on growth performance and nutrient utilization of Ross 308 broilers.

\begin{tabular}{|c|c|c|c|c|}
\hline \multirow{2}{*}{ Parameters } & \multicolumn{3}{|c|}{ Alpha-Monolaurin (g/kg) } & \multirow[b]{2}{*}{1} \\
\hline & $\mathbf{0}$ & 0.25 & 0.5 & \\
\hline Initial body weight, $\mathrm{g}$ & $47.42 \pm 0.13$ & $47.38 \pm 0.075$ & $47.55 \pm 0.062$ & $47.44 \pm 0.13$ \\
\hline Body weight at $7 \mathrm{~d}, \mathrm{~g}$ & $202.2 \pm 2.7$ & $206.3 \pm 4.2$ & $206.7 \pm 4.1$ & $205.5 \pm 4.0$ \\
\hline Feed intake, $\mathrm{g} / 7 \mathrm{~d}$ & $172.3 \pm 2.5$ & $170.2 \pm 2.1$ & $171.8 \pm 2.9$ & $173.8 \pm 3.1$ \\
\hline FCR, $7 \mathrm{~d}$ & $0.852 \pm 0.02$ & $0.825 \pm 0.03$ & $0.831 \pm 0.03$ & $0.846 \pm 0.05$ \\
\hline Body weight at $14 \mathrm{~d}, \mathrm{~g}$ & $514.2 \pm 9.4$ & $518.5 \pm 8.9$ & $520.2 \pm 8.2$ & $517.8 \pm 9.6$ \\
\hline Feed intake, g/14 d & $542.4 \pm 11.5$ & $538.7 \pm 12.1$ & $539.5 \pm 11.8$ & $540.7 \pm 12.2$ \\
\hline FCR, $14 \mathrm{~d}$ & $1.055 \pm 0.017^{\mathrm{a}}$ & $1.038 \pm 0.015^{b}$ & $1.037 \pm 0.013^{b}$ & $1.044 \pm 0.015^{\mathrm{a}, \mathrm{b}}$ \\
\hline Body weight at $21 \mathrm{~d}, \mathrm{~g}$ & $977.2 \pm 19.4$ & $986.5 \pm 18.6$ & $984.5 \pm 15.8$ & $980.3 \pm 17.4$ \\
\hline Feed intake, $\mathrm{g} / 21 \mathrm{~d}$ & $1185.2 \pm 23.2$ & $1175.5 \pm 26.2$ & $1172.3 \pm 25.2$ & $1180.4 \pm 24.8$ \\
\hline FCR, $21 \mathrm{~d}$ & $1.213 \pm 0.04^{\mathrm{a}}$ & $1.192 \pm 0.05^{b}$ & $1.191 \pm 0.06^{b}$ & $1.204 \pm 0.015^{\mathrm{a}, \mathrm{b}}$ \\
\hline Body weight at $28 \mathrm{~d}, \mathrm{~g}$ & $1549.6 \pm 28.4^{b}$ & $1576.2 \pm 31.2^{\mathrm{a}}$ & $1570.2 \pm 25.5^{a}$ & $1568.0 \pm 30.2^{\mathrm{a}, \mathrm{b}}$ \\
\hline
\end{tabular}


Table 2. Cont.

\begin{tabular}{|c|c|c|c|c|}
\hline \multirow{2}{*}{ Parameters } & \multicolumn{3}{|c|}{ Alpha-Monolaurin (g/kg) } & \multirow[b]{2}{*}{1} \\
\hline & 0 & 0.25 & 0.5 & \\
\hline Feed intake, $\mathrm{g} / 28 \mathrm{~d}$ & $2113.7 \pm 37.1$ & $2110.2 \pm 36.9$ & $2104.7 \pm 37.6$ & $2118.1 \pm 31.2$ \\
\hline FCR, $28 \mathrm{~d}$ & $1.364 \pm 0.017^{\mathrm{a}}$ & $1.339 \pm 0.015^{b}$ & $1.340 \pm 0.013^{b}$ & $1.351 \pm 0.015^{\mathrm{a}, \mathrm{b}}$ \\
\hline Body weight at $33 \mathrm{~d}, \mathrm{~g}$ & $1979.9 \pm 18.9$ & $2052.5 \pm 41.6$ & $2020.7 \pm 15.1$ & $2013.3 \pm 40.05$ \\
\hline Body weight gain, g/33 d & $1932.6 \pm 18.8$ & $2005.2 \pm 41.6$ & $1973.2 \pm 15.1$ & $1965.8 \pm 40.04$ \\
\hline Feed intake, $\mathrm{g} / 33 \mathrm{~d}$ & $2966.5 \pm 27.5$ & $2954.5 \pm 56.1$ & $2902.3 \pm 27.9$ & $2896.3 \pm 54.1$ \\
\hline FCR, $33 \mathrm{~d}$ & $1.499 \pm 0.017^{\mathrm{a}}$ & $1.440 \pm 0.015^{\mathrm{a}, \mathrm{b}}$ & $1.436 \pm 0.013^{b}$ & $1.439 \pm 0.015^{\mathrm{a}, \mathrm{b}}$ \\
\hline EPEF & $380.91 \pm 4.2^{b}$ & $411.42 \pm 3.9^{a}$ & $405.98 \pm 4.5^{\mathrm{a}, \mathrm{b}}$ & $403.6 \pm 4.8^{\mathrm{a}, \mathrm{b}}$ \\
\hline Mortality, \% & $1.66 \pm 0.23$ & $1.66 \pm 0.31$ & $1.66 \pm 0.12$ & $1.66 \pm 0.19$ \\
\hline CPU $(\%)$ & $81.6 \pm 0.6$ & $84.6 \pm 0.7$ & $82.7 \pm 0.7$ & $82.6 \pm 0.7$ \\
\hline CFU $(\%)$ & $42.9 \pm 0.8$ & $48.5 \pm 0.7$ & $45.5 \pm 1.1$ & $45.8 \pm 0.9$ \\
\hline EEU (\%) & $35.6 \pm 0.9^{c}$ & $54.3 \pm 0.8^{a}$ & $48.1 \pm 0.9^{b}$ & $44.4 \pm 0.5^{\mathrm{b}}$ \\
\hline $\mathrm{ME} \mathrm{kcal/kg}$ & $65.5 \pm 0.9$ & $67.3 \pm 0.6$ & $66.6 \pm 0.5$ & $66.7 \pm 0.9$ \\
\hline
\end{tabular}

${ }^{\mathrm{a}-\mathrm{c}}$ Means within the same row with different superscripts differ $(p<0.05)$. FCR $=$ feed conversion ratio; EPEF $=$ European production efficiency factor; $\mathrm{CPU}=$ crude protein utilization; $\mathrm{CFU}=$ crude fiber utilization; $\mathrm{EEU}=$ ether extract utilization.

Table 3. Effect of dietary alpha-monolaurin supplementation on organ weights of Ross 308 broilers at 33 days.

\begin{tabular}{ccccc}
\hline Parameters & \multicolumn{4}{c}{ Alpha-Monolaurin (g/kg) } \\
\cline { 2 - 5 } & $\mathbf{0}$ & $\mathbf{0 . 2 5}$ & $\mathbf{0 . 5}$ & $\mathbf{1}$ \\
\hline Carcass weight, g/100 g BW & $64.8 \pm 1.51$ & $63.2 \pm 3.02$ & $64.4 \pm 1.1$ & $61.7 \pm 4.9$ \\
Breast muscle weight, g/100 g BW & $25.0 \pm 1.8$ & $24.9 \pm 2.2$ & $23.9 \pm 2.1$ & $22.6 \pm 2.3$ \\
Thigh muscle weight, g/100 g BW & $17.6 \pm 1.3$ & $16.2 \pm 1.6$ & $16.7 \pm 1.6$ & $17.4 \pm 1.02$ \\
Liver weight, g/100 g BW & $2.6 \pm 0.16$ & $2.9 \pm 0.82$ & $2.6 \pm 0.69$ & $2.5 \pm 0.37$ \\
Gizzard weight, g/100 g BW & $0.94 \pm 0.32$ & $0.93 \pm 0.14$ & $0.99 \pm 0.12$ & $1.09 \pm 0.17$ \\
Abdominal fat, g/100 g BW & $1.68 \pm 0.33$ & $1.88 \pm 0.77$ & $1.71 \pm 0.40$ & $0.59 \pm 1.9$ \\
Spleen weight, g/100 g BW & $0.06 \pm 0.01^{\mathrm{b}}$ & $0.15 \pm 0.05^{\mathrm{a}}$ & $0.14 \pm 0.03^{\mathrm{a}}$ & $0.10 \pm 0.05^{\mathrm{a}, \mathrm{b}}$ \\
Heart weight, g/100 g BW & $0.534 \pm 0.09$ & $0.464 \pm 0.13$ & $0.523 \pm 0.10$ & $0.433 \pm 0.03$ \\
\hline
\end{tabular}

$\overline{\mathrm{a}, \mathrm{b}}$ Means within the same row with different superscripts differ $(p<0.05)$. BW = body weight.

\subsection{Blood Biochemical Traits}

The effects of alpha-monolaurin supplementation on blood plasma components of broilers are presented in Table 4. Dietary treatments had no significant effect on plasma total cholesterol, triglyceride, HDL-cholesterol, LDL-cholesterol, glucose, and creatinine. However, the plasma ALT level was significantly decreased by $0.5 \mathrm{~g} / \mathrm{kg}$ alpha-monolaurin concerning the control $(p \leq 0.05)$. Dietary alpha-monolaurin increased the total plasma protein and albumin concentrations, and the highest level was obtained at the level of $0.5 \mathrm{~g}$ alpha-monolaurin $/ \mathrm{kg}$ feed $(p \leq 0.05)$. 
Table 4. Impact of dietary alpha-monolaurin supplementation on plasma components of Ross 308 broilers at 33 days.

\begin{tabular}{ccccc}
\hline & \multicolumn{4}{c}{ Alpha-Monolaurin (g/kg) } \\
\cline { 2 - 5 } Parameters & $\mathbf{0}$ & $\mathbf{0 . 2 5}$ & $\mathbf{0 . 5}$ & $\mathbf{1}$ \\
\cline { 2 - 5 } & $167 \pm 5.5$ & $166.5 \pm 3.6$ & $172 \pm 6.5$ & $165 \pm 3.4$ \\
TC, mg/dL & $6.6 \pm 0.16$ & $6.25 \pm 0.14$ & $5.17 \pm 0.86$ & $6.0 \pm 0.21$ \\
TG, mg/dL & $63.3 \pm 2.1$ & $70.8 \pm 3.2$ & $68.0 \pm 4.3$ & $65.0 \pm 3.6$ \\
HDL, mg/dL & $58.0 \pm 3.1$ & $51.6 \pm 4.9$ & $47.5 \pm 4.1$ & $52.5 \pm 2.4$ \\
LDL, mg/dL & $145 \pm 9.6$ & $125 \pm 7.9$ & $148 \pm 7.1$ & $150 \pm 10.4$ \\
Glucose, mg/dL & $178.8 \pm 25$ & $168.5 \pm 45^{\circ}$ & $146 \pm 26$ & $193.5 \pm 24$ \\
AST (IU/I) & $6.4 \pm 1.1^{\mathrm{a}}$ & $4.4 \pm 0.49^{\mathrm{b}}$ & $4.6 \pm 0.54^{\mathrm{b}}$ & $5.6 \pm 0.64^{\mathrm{a}, \mathrm{b}}$ \\
ALT (IU/I) & $0.622 \pm 0.11$ & $0.713 \pm 0.03$ & $0.693 \pm 0.06$ & $0.683 \pm 0.02$ \\
Creatinine, mg/dL & $3.25 \pm 0.26^{\mathrm{b}}$ & $3.37 \pm 0.25^{\mathrm{b}}$ & $5.13 \pm 0.58^{\mathrm{a}}$ & $3.68 \pm 0.23^{\mathrm{b}}$ \\
TP, mg/dL & $1.73 \pm 0.08^{\mathrm{b}}$ & $1.85 \pm 0.18^{\mathrm{b}}$ & $3.75 \pm 0.27^{\mathrm{a}}$ & $2.09 \pm 0.43^{\mathrm{b}}$ \\
Albumin, mg/dL & $1.52 \pm 0.23$ & $1.52 \pm 0.24$ & $1.38 \pm 0.37$ & $1.52 \pm 0.32$ \\
Globulin, mg/dL &
\end{tabular}

a,b Means within the same row with different superscripts differ $(p<0.05)$. TC $=$ total cholesterol, $\mathrm{TG}=$ triglyceride, $\mathrm{HDL}=$ high-density lipoprotein, $\mathrm{LDL}=$ low-density lipoprotein, $\mathrm{ALT}=$ alanine transaminase, $\mathrm{AST}=$ aspartate aminotransferase, $\mathrm{TP}=$ total protein .

\subsection{Fatty Acid Composition and Lipid Peroxidation}

Regarding the effect of alpha-monolaurin supplementation on linolenic and oleic fatty acid composition in breast muscle and MDA content in the liver (Figure 1A-C), it was observed that dietary alpha-monolaurin significantly increased the linolenic and oleic fatty acid content in breast muscle $(p \leq 0.05)$. The highest level of linolenic acid was observed in birds fed $1 \mathrm{~g}$ alpha-monolaurin $/ \mathrm{kg}$ feed. In contrast, the most elevated oleic fatty acid level was in birds fed $0.5 \mathrm{~g}$ alpha-monolaurin $/ \mathrm{kg}$ feed $(p \leq 0.05)$. Conversely, the MDA levels were significantly reduced in birds provided with a level of 0.25 and $1 \mathrm{~g}$ alpha-monolaurin $/ \mathrm{kg}$ feed compared to the control, without a significant difference from birds fed at $0.5 \mathrm{~g} / \mathrm{kg}(p \geq 0.05)$.

\subsection{Resistance to ND}

Dietary alpha-monolaurin supplementation enhanced the antibody titers against ND compared to the control diet after 2 and 3 weeks of ND infections $(p \leq 0.05)$ (Figure 2). The most significant resistance was observed in birds fed $1 \mathrm{~g}$ alpha-monolaurin $/ \mathrm{kg}$ feed after two weeks $(p \leq 0.05)$. In contrast, no differences were observed among birds fed $0.25,0.5$, and $1 \mathrm{~g}$ alpha-monolaurin $/ \mathrm{kg}$ feed after 3 weeks $(p \geq 0.05)$. 

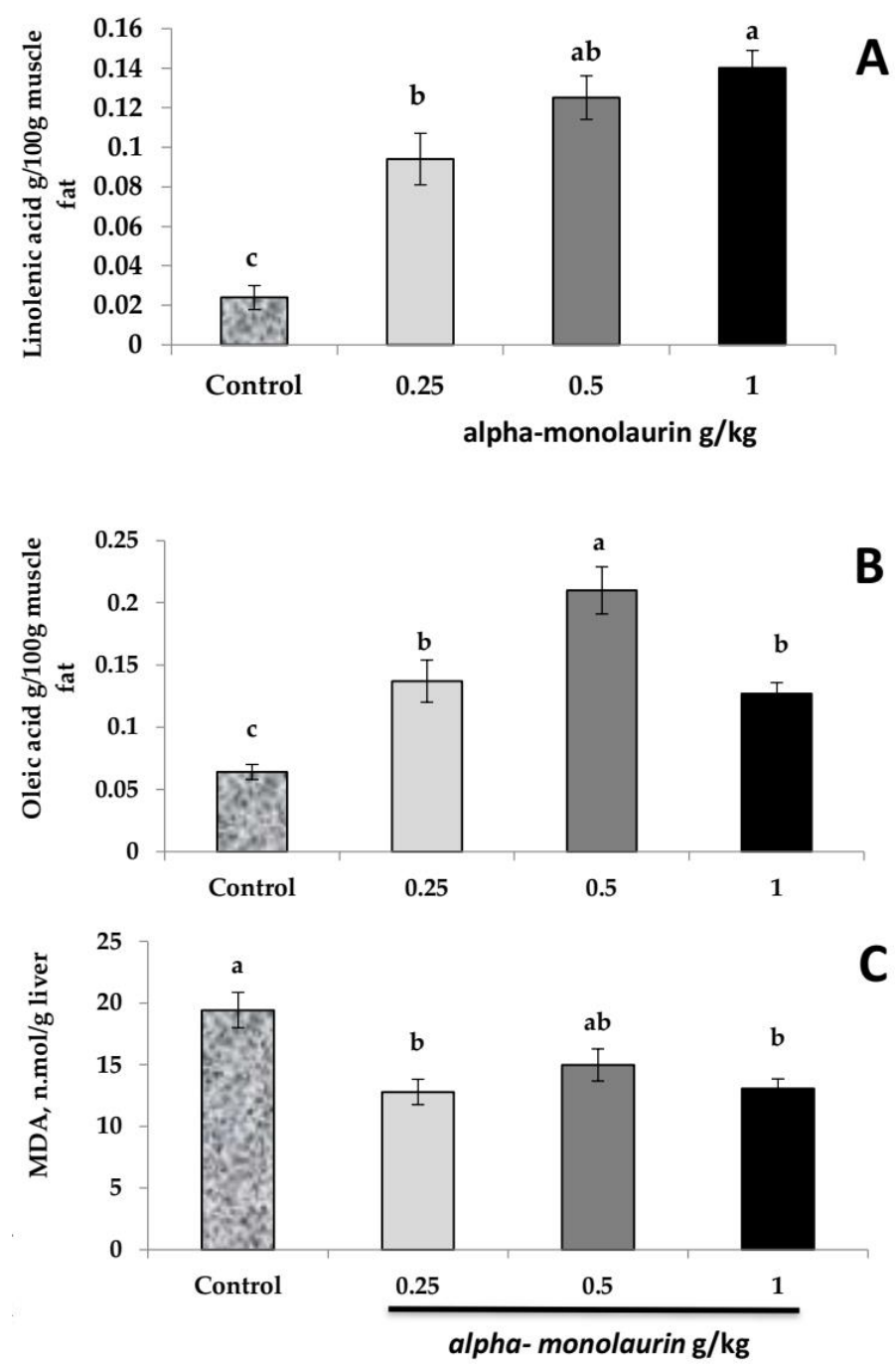

Figure 1. Effect of dietary alpha-monolaurin supplementation on fatty acid composition in breast muscle linolenic acid (A), oleic acid (B), and MDA in the liver (C). ${ }^{\mathrm{a}-\mathrm{c}}$ Means within the same row with different superscripts differ $(p<0.05)$. Values are presented as means \pm SE of 12 samples per group.

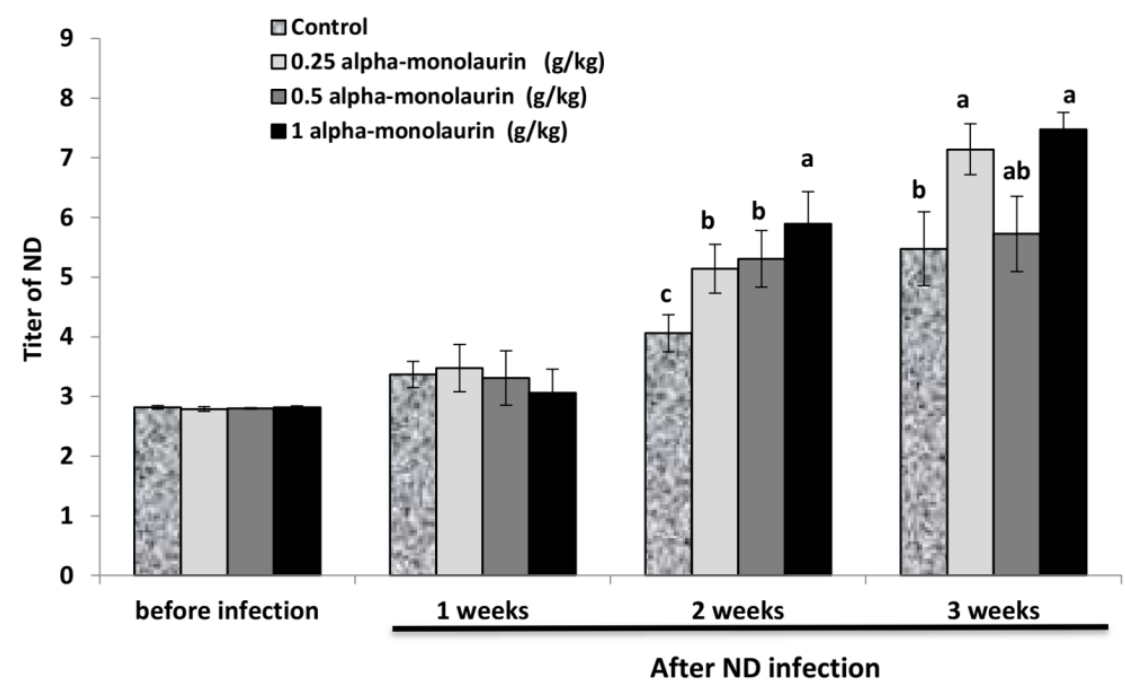

Figure 2. Effect of dietary alpha-monolaurin supplementation on immune response in broilers. ${ }^{\mathrm{a}-\mathrm{c}}$ Means within the same row with different superscripts differ $(p<0.05)$. Values are presented as means \pm SE of 12 samples per group. 


\section{Discussion}

Our dietary alpha-monolaurin was used as a growth promotor and immunostimulant in chicks $[28,29]$. Although no significant enhancement was observed on the final weight and weight gain of broilers fed alpha-monolaurin, the FCR and ether extract utilization were affected by dietary alpha-monolaurin. The FCR presents the relation between weight gain and consumed feed, and the reduced value of FCR refers to enhanced weight gain in broilers with proper feed intake. The FCR also correlates with improved feed efficiency in the bird's gut, which can be attributed to the activated digestive enzymes by dietary alpha-monolaurin [29,30]. Zeitz, Fennhoff, Kluge, Stangl, and Eder [30] reported that alpha-monolaurin could affect the digestion capacity in the gut of birds and facilitates the absorption capacity of nutrients. Similarly, Mustafa [24] reported that dietary alphamonolaurin lowered the FCR in broilers.

Monolaurin has recently gained more attention due to its possible antimicrobial effects. Intestinal health performance can be improved by monolaurin 4 and $12 \%$ for increased BW and FCR, respectively [31]. Dietary monolaurin has been documented to improve growth and intrinsic histomorphology and reduce intestinal pathogens [32]. Many studies have shown that monolaurin's efficacy in stimulating bird growth results in an improved gastrointestinal ecology, including the resulting intestinal ecosystem, intestinal mucosal integrity, and digestive and immune statuses of the GIT [33]. Other studies have not shown any increase in broiler efficiency compared to control birds and antibiotic-fed birds compared to those fed monolaurin-complemented diets [34].

Some studies have linked the impact of monolaurin to the epithelial function in the upper gut directly or indirectly by raising the absorbing surface, increasing the absorption, and generating a higher use of nutrients for development. Intestinal cells can use monolaurin immediately to generate energy and thus promote intestinal integrity in piglets after weaning [35]. Rats supplemented with monolaurin diets showed an enhanced GIT morphology with an increased mucous membrane, longer intestinal villi, shorter crypt, increased phospholipid/protein ratio of jejunal mucous lipids, and enhanced membrane-bound enzyme activity [36]. Spleen weight was significantly increased by alpha-monolaurin; however, other organ weights were not affected. These results agree with London, Manalu, and Wiryawan [13], who found that the lauric acid source did not influence the dressing percentages (carcass, muscle, and abdominal fat weights) of chickens. Our results disagree with Liu et al. [37]. They reported that dietary alpha-monolaurin enhanced carcass characteristics, suggesting that dietary alpha-monolaurin increased growth efficiency and increased the production of lean meat in broilers. The improvement in eviscerated yields and the leg and breast muscles by supplementation with alpha-monolaurin could be correlated with increased protein deposition in broilers, as total protein in serum was significantly increased.

The results of the biochemical blood variables are essential in evaluating the general health condition of broilers $[5,21,38]$. They also indicate the impact of nutritional strategies and dietary feed additives on the performances of birds. The current study data report that plasma total protein and albumin were substantially increased by dietary alpha-monolaurin, while liver ALT was decreased. In the same sense, Seleem et al. [39] reported that alphamonolaurin supplementation reduced the ALT level, which indicates its safety without any harmful activity on liver functions. However, the results disagree with Mustafa [24], who found that ALT and AST were increased by feeding high-dose monolaurin at $8 \mathrm{~g} / \mathrm{kg}$, which confirms that the high levels of alpha-monolaurin could impair liver function. The enhanced total protein and albumin levels can be clarified by alpha-monolaurin's role in improving the feed digestibility and protein level in the blood.

Plasma lipids (total cholesterol, triglyceride, HDL-cholesterol, LDL-cholesterol) were not affected by alpha-monolaurin supplementation in the current experiment; this agrees with Baltić et al. [40], who showed HDL-C levels were not significantly affected by MCFA supplementation in broilers. However, our results disagree with those of Liu et al. [37], who reported an improvement in serum HDL-cholesterol in birds fed medium-chain a- 
monoglycerides at 300 and $450 \mathrm{mg} / \mathrm{kg}$. Modification of the lipid serum profile showed that dietary glycerides in the medium chain effectively increase broiler fat metabolism. MCFA and glycerides associated with increased cholesterol carriage led to lower serum cholesterol levels [41-43].

Stressful conditions cause the overproduction of reactive oxygen metabolites, impairing the cells by increasing the lipid peroxidation measured by detecting the MDA concentration [44]. Moreover, the oxidative injury in birds sequentially shrinks growth and meat quality. Consequently, the antioxidant activity of food additives plays a crucial role in poultry production, so the reduction in MDA by alpha-monolaurin may be owing to augmentation effects of monolaurin on gut activity, pro-inflammatory cytokines, and antimicrobial and antiviral effects. The present study showed that liver MDA was significantly reduced in birds fed 0.25 and $1 \mathrm{~g}$ alpha-monolaurin $/ \mathrm{kg}$ feed compared to the control, without a significant difference from birds fed $0.5 \mathrm{~g} / \mathrm{kg}$. Linolenic and oleic fatty acids were increased by alpha-monolaurin supplementation. Monolaurin has been reported for its ability to induce antioxidative and antibacterial activities [28,45]. The increase in muscle unsaturated fatty acid content (oleic and linolenic fatty acids) may be due to decreased lipid peroxidation [46-51]. Moreover, Londok, Sumiati, Wiryawan, and Manalu [13] found that unsaturated fatty acids were increased by lauric acid supplementation in broiler diets.

The present study uniquely displayed an increased ND titer after infection, which confirms the antiviral effect of monolaurin in broilers. Splenic gene expression represents a systemic immune function in chickens because the spleen serves as both a reservoir and an activation site for leukocytes [52]. In this study, spleen weight and plasma proteins were increased by dietary monolaurin, which is evidence for an improved immune response. However, more data on the role of monolaurin for gene expression-related immunity are needed in the future. The active properties of monolaurin are considered to be antimicrobial and antiviral, making it more effective than other monoacylglycerols. Monolaurin is a monoacylglycerol with a polar or hydrophilic head (glycerol), whereas the acyl/tail (laurate) is non-polar or hydrophobic monolaurin. Previous studies indicated that the membrane of enveloped viruses is efficient in destroying monolaurin and its products, such as lauric acid and lauryl sulfate [53]. Monolaurin's ability to prevent replication for many different forms of viruses suggests that monolaurin has tremendous potential for pharmaceutical and medical purposes in preventing virus attacks.

\section{Conclusions}

Dietary alpha-monolaurin at 0.25 to $0.5 \mathrm{~g} / \mathrm{kg}$ improved the feed conversion ratio, lipid content, and peroxidation by increasing muscle unsaturated fatty acids, decreasing liver MDA content, and increasing resistance to the antibody titer of ND in chicken broilers. Furthermore, the current data verify that dietary alpha-monolaurin supplementation had no adverse effect on liver functions and plasma lipids.

Author Contributions: Conceptualization, A.A.S., B.E.-G., N.B., Y.E., M.S., S.S., and M.D.; formal analysis, A.H., S.S., A.A.S., B.E.-G., and Y.E.; funding acquisition, S.S. and M.S.; investigation, B.E.-G., Y.E., and M.D.; project administration, A.A.S.; supervision, A.A.S., N.B., and Y.E.; writing-original draft, A.A.S. and M.D.; writing-review and editing, S.S. and A.H. All authors have read and agreed to the published version of the manuscript.

Funding: This work was supported by the Deanship of Scientific Research at Taif University, Research Supporting Project number (TURSP-2020/76), Taif University, Taif, Saudi Arabia.

Institutional Review Board Statement: Not applicable.

Informed Consent Statement: Not applicable.

Data Availability Statement: Data supporting this study's findings are available upon fair request from the corresponding author.

Acknowledgments: The authors would like to extend their sincere appreciation to all staff members of Poultry production department, Faculty of Agriculture, Kafrelsheikh University, Egypt. 
Conflicts of Interest: No conflict of interest.

\section{References}

1. De Oliveira, L.S.; Balbino, E.M.; Silva, T.N.S.; Ily, L.; da Rocha, T.C.; de Oliveira Strada, E.S.; Pinheiro, A.M.; de Brito, J.A.G. Use of emulsifier and lipase in feeds for broiler chickens. Semin. Ciências Agrárias 2019, 40, 3181-3196. [CrossRef]

2. Wade, B.; Keyburn, A. The true cost of necrotic enteritis. World Poult. 2015, 31, 16-17.

3. Lara, L.J.; Rostagno, M.H. Impact of heat stress on poultry production. Animals 2013, 3, 356-369. [CrossRef] [PubMed]

4. Bengtsson, B.; Greko, C. Antibiotic resistance-Consequences for animal health, welfare, and food production. Upsala J. Med Sci. 2014, 119, 96-102. [CrossRef] [PubMed]

5. Saleh, A.A.; Elnagar, A.M.; Eid, Y.Z.; Ebeid, T.A.; Amber, K.A. Effect of feeding wheat middlings and calcium lignosulfonate as pellet binders on pellet quality growth performance and lipid peroxidation in broiler chickens. Vet. Med. Sci. 2020, 1-10. [CrossRef] [PubMed]

6. Guo, F.C.; Kwakkel, R.P.; Soede, J.; Williams, B.A.; Verstegen, M.W.A. Effect of a chinese herb medicine formulation, as an alternative for antibiotics, on performance of broilers. Br. Poult. Sci. 2004, 45, 793-797. [CrossRef] [PubMed]

7. Saleh, A.A.; Paray, B.A.; Dawood, M.A.O. Olive cake meal and bacillus licheniformis impacted the growth performance, muscle fatty acid content, and health status of broiler chickens. Animals 2020, 10, 695. [CrossRef]

8. El-Deep, M.H.; Amber, K.A.; Elgendy, S.; Dawood, M.A.O.; Zidan, A. In ovo injection of nano-selenium spheres mitigates the hatchability, histopathology image and immune response of hatched chicks. J. Anim. Physiol. Anim. Nutr. 2020, 104, 1392-1400. [CrossRef]

9. Fahmy, Z.H.; Aly, E.; Mohamed, A.H. The effect of medium chain saturated fatty acid (monolaurin) on levels of the cytokines on experimental animal in entamoeba histolytica and giardia lamblia infection. Afr. J. Pharm. Pharmacol. 2014, 8, 106-114.

10. Zentek, J.; Buchheit-Renko, S.; Ferrara, F.; Vahjen, W.; Van Kessel, A.; Pieper, R. Nutritional and physiological role of medium-chain triglycerides and medium-chain fatty acids in piglets. Anim. Health Res. Rev. 2011, 12, 83-93. [CrossRef] [PubMed]

11. Kabara, J.J.; Swieczkowski, D.M.; Conley, A.J.; Truant, J.P. Fatty acids and derivatives as antimicrobial agents. Antimicrob. Agents Chemother. 1972, 2, 23-28. [CrossRef]

12. Ettinger, M. Antiviral and antibacterial actions of monolaurin and lauric acid. Mol. Cell Biochem. 2005, 272, 29-34.

13. Londok, J.J.M.R.; Sumiati, S.; Wiryawan, I.K.G.; Manalu, W. Antioxidant enzyme activity and malondialdehyde concentration on broiler fed contain lauric acid and areca vestiaria giseke. Bul. Peternak. 2018, 42. [CrossRef]

14. Lieberman, S.; Enig, M.G.; Preuss, H.G. A review of monolaurin and lauric acid: Natural virucidal and bactericidal agents. Altern. Complementary Ther. 2006, 12, 310-314. [CrossRef]

15. Mustafa, N.G. Biochemical trails associated with different doses of alpha-monolaurin in chicks. Adv. Anim. Vet. Sci. 2019, 7, 187-192. [CrossRef]

16. Isaacs, C.E.; Thormar, H.; Pessolano, T. Membrane-disruptive effect of human milk: Inactivation of enveloped viruses. J. Infect. Dis. 1986, 154, 966-971. [CrossRef] [PubMed]

17. Preuss, H.G.; Echard, B.; Enig, M.; Brook, I.; Elliott, T.B. Minimum inhibitory concentrations of herbal essential oils and monolaurin for gram-positive and gram-negative bacteria. Mol. Cell. Biochem. 2005, 272, 29-34. [CrossRef]

18. Fortuoso, B.F.; Dos Reis, J.H.; Gebert, R.R.; Barreta, M.; Griss, L.G.; Casagrande, R.A.; de Cristo, T.G.; Santiani, F.; Campigotto, G.; Rampazzo, L.; et al. Glycerol monolaurate in the diet of broiler chickens replacing conventional antimicrobials: Impact on health, performance and meat quality. Microb. Pathog. 2019, 129, 161-167. [CrossRef] [PubMed]

19. Witcher, K.J.; Novick, R.P.; Schlievert, P.M. Modulation of Immune Cell Proliferation by Glycerol Monolaurate. Clin. Diagn. Lab. Immunol. 1996, 3, 10-13. [CrossRef]

20. Zhang, M.S.; Sandouk, A.; Houtman, J.C.D. Glycerol Monolaurate (GML) inhibits human T-cell signaling and function by disrupting lipid dynamics. Sci. Rep. 2016, 6, 1-13. [CrossRef]

21. Bartolotta, S.; Garc, C.C.; Candurra, N.A.; Damonte, E.B. Effect of fatty acids on arenavirus replication: Inhibition of virus production by lauric acid. Arch. Virol. 2001, 146, 777-790. [CrossRef]

22. Arora, R.; Chawla, R.; Marwah, R.; Arora, P.; Sharma, R.K.; Kaushik, V.; Goel, R.; Kaur, A.; Silambarasan, M.; Tripathi, R.P.; et al. Potential of complementary and alternative medicine in preventive management of novel H1N1 flu (swine flu) pandemic: Thwarting potential disasters in the bud. Evidence-Based Complementary Altern. Med. 2011, 586506. [CrossRef] [PubMed]

23. Hilmarsson, H.; Traustason, B.S.; Kristmundsdóttir, T.; Thormar, H. Virucidal activities of medium- and long-chain fatty alcohols and lipids against respiratory syncytial virus and parainfluenza virus type 2: Comparison at different pH levels. Arch. Virol. 2007, 152, 2225-2236. [CrossRef]

24. Ruzin, A.; Novick, R.P. Equivalence of Lauric Acid and Glycerol Monolaurate as Inhibitors of Signal Transduction in Staphylococcus aureus. J. Bacteriol. 2000, 182, 2668-2671. [CrossRef]

25. AOAC. Official Methods of Analysis, 19th ed.; Association of Official Agricultural Chemists: Arlington, VA, USA, 1994.

26. Saleh, A.A. Effects of fish oil on the production performances, polysaturated fatty acids and cholesterol levels of yolk in hens. Emir. J. Food Agric. 2013, 25, 605-612. [CrossRef]

27. OIE. Manual of Diagnostic Tests and Vaccines for Terrestrial Animals; OIE: Paris, France, 2008; pp. 1092-1106.

28. Londok, J.; Manalu, W.; Wiryawan, K.G. Growth performance, carcass characteristics and fatty acids profile of broilers supplemented with lauric acid and natural antioxidant from areca vestiaria giseke. Pak. J. Nutr. 2017, 16, 719-731. [CrossRef] 
29. Saleh, A.; Ahmed, E.; Ebeid, A. The impact of phytoestrogen source supplementation on reproductive performance, plasma profile, yolk fatty acids and antioxidative status in aged laying hens. Reprod. Domest. Anim. 2019, 54, 846-854. [CrossRef] [PubMed]

30. Zeitz, J.; Fennhoff, J.; Kluge, H.; Stangl, G.; Eder, K. Effects of dietary fats rich in lauric and myristic acid on performance, intestinal morphology, gut microbes, and meat quality in broilers. Poult. Sci. 2015, 94, 2404-2413. [CrossRef]

31. Çenesiz, A.; Çiftci, İ. Modulatory effects of medium chain fatty acids in poultry nutrition and health. World's Poult. Sci. J. 2020, 27, 1-15. [CrossRef]

32. Khosravinia, H. Effect of dietary supplementation of medium-chain fatty acids on growth performance and prevalence of carcass defects in broiler chickens raised in different stocking densities. J. Appl. Poult. Res. 2015, 24, 1-9. [CrossRef]

33. Mountzouris, K.; Tsitrsikos, P.; Palamidi, I.; Arvaniti, A.; Mohnl, M.; Schatzmayr, G.; Fegeros, K. Effects of probiotic inclusion levels in broiler nutrition on growth performance, nutrient digestibility, plasma immunoglobulins, and cecal microflora composition. Poult. Sci. 2010, 89, 58-67. [CrossRef]

34. Vieira, S.L.; Oyarzabal, O.; Freitas, D.; Berres, J.; Pena, J.; Torres, C.; Coneglian, J. Performance of broilers fed diets supplemented with sanguinarine-like alkaloids and organic acids. J. Appl. Poult. Res. 2008, 17, 128-133. [CrossRef]

35. Guillot, E.; Vaugelade, P.; Lemarchali, P.; Rat, A.R. Intestinal absorption and liver uptake of medium-chain fatty acids in non-anaesthetized pigs. Biritish J. Nutr. 1993, 69, 431-442. [CrossRef]

36. Takase, S.; Goda, T. Effects of medium-chain triglycerides on brush border membrane-bound enzyme activity in rat small intestine. J. Nutr. 1990, 120, 969-976. [CrossRef] [PubMed]

37. Liu, T.; Li, C.; Zhong, H.; Feng, F. Dietary medium-chain $\alpha$-monoglycerides increase BW, feed intake, and carcass yield in broilers with muscle composition alteration. Poult. Sci. 2021, 100, 186-195. [CrossRef] [PubMed]

38. Livingston, M.L.; Cowieson, A.J.; Crespo, R.; Hoang, V.; Nogal, B.; Browning, M.; Livingston, K.A. Effect of broiler genetics, age, and gender on performance and blood chemistry. Heliyon 2020, 6, e04400. [CrossRef] [PubMed]

39. Seleem, D.; Chen, E.; Benso, B.; Pardi, V.; Murata, R.M.J.P. In vitro evaluation of antifungal activity of monolaurin against candida albicans biofilms. PeerJ 2016, 4, e2148. [CrossRef]

40. Baltić, B.; Ćirić, J.; Šefer, D.; Radovanović, A.; Đorđević, J.; Glišić, M.; Bošković, M.; Baltić, M.Ž.; Đorđević, V.; Marković, R. Effect of dietary supplementation with medium chain fatty acids on growth performance, intestinal histomorphology, lipid profile and intestinal microflora of broiler chickens. South Afr. J. Anim. Sci. 2018, 48, 885-896. [CrossRef]

41. Projan, S.J.; Brown-Skrobot, S.; Schlievert, P.M.; Vandenesch, F.; Novick, R.P. Glycerol monolaurate inhibits the production of beta-lactamase, toxic shock toxin-1, and other staphylococcal exoproteins by interfering with signal transduction. J. Bacteriol. 1994, 176, 4204-4209. [CrossRef]

42. Zhang, X.; Zhang, Y.; Liu, Y.; Wang, J.; Xu, Q.; Yu, X.; Yang, X.; Liu, Z.; Xue, C. Medium-chain triglycerides promote macrophage reverse cholesterol transport and improve atherosclerosis in ApoE-deficient mice fed a high-fat diet. Nutr. Res. 2016, 36, 964-973. [CrossRef]

43. Zhou, S.; Wang, Y.; Jacoby, J.r.J.; Jiang, Y.; Zhang, Y.; Yu, L.L. Effects of medium-and long-chain triacylglycerols on lipid metabolism and gut microbiota composition in C57BL/6J mice. J. Agric. Food Chem. 2017, 65, 6599-6607. [CrossRef]

44. Yao, J.; Wang, J.-Y.; Liu, L.; Li, Y.-X.; Xun, A.-Y.; Zeng, W.-S.; Jia, C.-H.; Wei, X.-X.; Feng, J.-L.; Zhao, L. Anti-oxidant effects of resveratrol on mice with dss-induced ulcerative colitis. Arch. Med. Res. 2010, 41, 288-294. [CrossRef]

45. Moradi, M.; Tajik, H.; Razavi Rohani, S.M.; Mahmoudian, A. Antioxidant and antimicrobial effects of zein edible film impregnated with zataria multiflora boiss. Essential oil and monolaurin. LWT Food Sci. Technol. 2016, 72, 37-43. [CrossRef]

46. Ladeira, M.M.; Santarosa, L.C.; Chizzotti, M.L.; Ramos, E.M.; Neto, O.R.M.; Oliveira, D.M.; Carvalho, J.R.R.; Lopes, L.S.; Ribeiro, J.S. Fatty acid profile, color and lipid oxidation of meat from young bulls fed ground soybean or rumen protected fat with or without monensin. Meat Sci. 2014, 96, 597-605. [CrossRef]

47. Oviedo-Rondón, E.O. Holistic view of intestinal health in poultry. Anim. Feed Sci. Technol. 2019, 250, 1-8. [CrossRef]

48. Saleh, A.A.; Amber, K.A.; Mousa, M.M.; Nada, A.L.; Awad, W.; Dawood, M.A.O.; El-Moneim, A.E.-M.E.A.; Ebeid, T.A.; AbdelDaim, M.M. A mixture of exogenous emulsifiers increased the acceptance of broilers to low energy diets: Growth performance, blood chemistry, and fatty acids traits. Animals 2020, 10, 437. [CrossRef]

49. Kirrella, A.A.; Abdo, S.E.; El-Naggar, K.; Soliman, M.M.; Aboelenin, S.M.; Dawood, M.A.O.; Saleh, A.A. Use of Corn Silk Meal in Broiler Diet: Effect on Growth Performance, Blood Biochemistry, Immunological Responses, andGrowth-Related Gene Expression. Animals 2021, 11, 1170. [CrossRef] [PubMed]

50. Saleh, A.A.; Gawish, E.; Mahmoud, S.F.; Amber, K.; Awad, W.; Alzawqari, M.H.; Shukry, M.; Abdel-Moneim, A.-M.E. Effect of Natural and Chemical Colorant Supplementation on Performance, Egg-Quality Characteristics, Yolk Fatty-Acid Profile, and BloodConstituents in Laying Hens. Sustainability 2021, 13, 4503. [CrossRef]

51. Saleh, A.A.; El-Awady, A.; Amber, K.; Eid, Y.Z.; Alzawqari, M.H.; Selim, S.; Soliman, M.M.; Shukry, M. Effects of Sunflower Meal Supplementation as a Complementary Protein Source in the Laying Hen's Diet on Productive Performance, Egg Quality, and Nutrient Digestibility. Sustainability 2021, 13, 3557. [CrossRef]

52. Kumar, S.; Ciraci, C.; Redmond, S.; Chuammitri, P.; Andreasen, C.; Palić, D.; Lamont, S. Immune response gene expression in spleens of diverse chicken lines fed dietary immunomodulators. Poult. Sci. 2011, 90, 1009-1013. [CrossRef] [PubMed]

53. Piret, J.; Desormeaux, A.; Bergeron, M.G. Sodium Lauryl Sulfate, a Microbicide Effective Against Enveloped and Nonenveloped Viruses. Curr. Drug Targets 2005, 3, 17-30. [CrossRef] [PubMed] 